\title{
Pengaruh Bauran Pemasaran (7p) terhadap Keputusan Pembelian Motor Yamaha Tipe Nmax
}

\section{Pengaruh Bauran Pemasaran (7p) terhadap Keputusan Pembelian Motor Tipe Yamaha NmaxTitle}

\author{
Samron Akhiri \\ Sekolah Tinggi Ilmu Ekonomi Prabumulih \\ samronakhiri.stie@gmail.com
}

\begin{abstract}
The purpose of the research to determine the effect of marketing mix (7p) Buying Decision Against Type Nmax At Yamaha Motor PD. Panca Motor Prabumulih This type of research is the method used in this research is survey method. Data collected consist of primary data and secondary data. The primary data obtained through interviews method which is equipped with a questionnaire has been prepared. In this study the number of population is not known, therefore, that according to Widiyanto in Vina Agustina (2012: 56) to determine the sample size of the population can use the formula. So a sample to be used is a total of 96 customers in PD. Panca Motor Prabumulih. Respondent data collected by collecting primary data, which collects data by distributing questionnaires were collected by questionnaire purchasing decisions. Data was analyzed using correlation and regression analysis. The results showed that, of the model output obtained summary table of test results gives the coefficient of determination $R$ Square of 0.744 . This shows that the variable marketing mix (product, price, distribution, promotion, people, process and physical environment) simultaneously percentage contribution of the influence of independent variables have an influence on the dependent variable (Decision consumers to shop), amounting to $74.4 \%$. Or the independent variable (product, price, distribution, promotion of people, processes and physical environment) amounted to $74.4 \%$ were able to explain the dependent variable (Decision consumers to shop), while the remaining $25.6 \%$ influenced or explained by other variables not examined in this research.
\end{abstract}

Keywords: Marketing Mix (7P), Purchase Decision

\begin{abstract}
ABSTRAK
Tujuan penelitian untuk mengetahui pengaruh bauran pemasaran (7p) terhadap Keputusan Pembelian Tipe Nmax Di Yamaha Motor PD. Panca Motor Prabumulih Jenis penelitian ini adalah metode yang digunakan dalam penelitian ini adalah metode survei. Data yang dikumpulkan terdiri dari data primer dan data sekunder. Data primer diperoleh melalui metode wawancara yang dilengkapi dengan kuesioner yang telah disiapkan. Dalam penelitian ini jumlah populasi tidak diketahui, oleh karena itu, bahwa menurut Widiyanto dalam Vina Agustina (2012: 56) untuk menentukan ukuran sampel populasi dapat menggunakan rumus. Jadi sampel yang akan digunakan adalah total 96 pelanggan di PD. Panca Motor Prabumulih. Data responden dikumpulkan dengan mengumpulkan data primer, yang mengumpulkan data dengan menyebarkan kuesioner dikumpulkan dengan keputusan pembelian kuesioner. Data dianalisis menggunakan analisis korelasi dan regresi. Hasil penelitian menunjukkan bahwa, dari model output diperoleh tabel ringkasan hasil pengujian memberikan koefisien determinasi $\mathrm{R}$ Square sebesar 0,744. Hal ini menunjukkan bahwa variabel bauran pemasaran (produk, harga, distribusi, promosi, orang, proses dan lingkungan fisik) secara simultan kontribusi persentase dari variabel independen mempunyai pengaruh terhadap variabel dependen (Keputusan konsumen untuk berbelanja), sebesar 74,4\%. Atau variabel independen (produk, harga, distribusi, promosi orang, proses dan lingkungan fisik) sebesar $74,4 \%$ mampu menjelaskan variabel dependen (Keputusan konsumen untuk berbelanja), sedangkan sisanya $25,6 \%$ dipengaruhi atau dijelaskan oleh variabel lain yang tidak diperiksa dalam penelitian ini.
\end{abstract}

Kata kunci: Bauran Pemasaran (7P), Keputusan Pembelian

MSEJ, 1(1) 2020: 50-63, http://journal.yrpipku.com/index.php/msej | DOI xxxxxxxxxxxxxxxxxxxxxx Copyright (C 2019 THE AUTHOR(S). This article is distributed under a a Creative Commons Attribution-NonCommercial 4.0 International license. 


\section{Pendahuluan}

Pada masa sekarang sepeda motor sangat dibutuhkan oleh manusia untuk membantu mempermudah mereka dalam menjalankan aktivitas dam pekerjaan. Beberapa sepeda motor jenis bebek (underbone) diparkir di sebuah restoran. bagian belakang motor dimodifikasi untuk mengangkut barang. Dengan sepeda motor itu, pesanan makanan pun siap diantar sampai ke rumah. Tidak hanya itu, sepeda motor juga sudah menjadi sarana transportasi publik, bagaikan taksi. Sebagai contoh, tukang ojek dapat kita temui di hampir seluruh Kota di Indonesia tarif jasa ojek sangat bervariasi, mulai dari tiga ribu rupiah sampai puluhan ribu rupiah, tergantung dari jarak yang ditempuh. Ojek sudah menjamur dan menjadi peluang investasi sektor jasa.

Dengan fenomena itu, industri sepeda motor ibarat tidak pernah kehilangan pasar. Pangsa pasar sepeda motor terus meningkat. Dan secara serta-merta pengelola parkir, termasuk Pemerintah, pun akan mendapatkan tambahan pendapatan dengan meningkatnya pasar motor di Indonesia. Mengapa permintaan sepeda motor terus meningkat? Pertanyaan itu memang terkesan sepele. Secara sederhana, dapat dijawab bahwa pangsa pasar besar. Populasi penduduk, kebutuhan masyarakat terhadap sepeda motor sebagai sarana berinvestasi untuk menjalankan kegiatan usaha dan perdagangan barang dan jasa cukup tinggi.

Yamaha memproduksi sepeda motor matic pertama yang pada awalnya diperuntukkan khusus untuk perempuan. Sepeda motor matic adalah tipe sepeda motor otomatis yang tidak menggunakan operasi gigi manual dan hanya cukup dengan satu ekselerasi, sepeda motor ini memiliki kapasitas silinder (CC) kecil posisi pengemudi yang teguk, ukuran sepeda motor ini lebih kecil dan ringan daripada tipe bebek. Sepeda motor ini memiliki ruang kosong di antara kemudi dan pengendara yang memungkinkan untuk kaki bisa diletakkan di tempat tersebut. Sepeda motor ini sangat cocok untuk wanita, pria, remaja maupun orang dewasa dan ini digunakan untuk keperluan dalam kota/wilayah. Sepeda motor tipe ini memiliki dimensi ukuran dan roda yang cukup kecil. Sepeda motor matic yamaha terkenal dengan iklannya yang menarik karena menggandeng artis-artis muda dan sangat terkenal.

Yamaha sendiri memiliki beberapa jenis sepeda motor seperti matic, bebek dan sport, tetapi saat ini yang banyak digemari adalah sepeda motor Yamaha matic. Saat ini di kota Prabumulih banyak berbagai macam merek kendaraan sepeda motor matic antara lain yamaha tipe NMAX yang terbaru, honda beat, honda vario dan scoopy dan ada banyak sepeda motor matic yang sangat digemari oleh masyarakat dari berbagai kalangan, selain desainnya yang cantik serta bodinya yang ramping sepeda motor matic juga mempermudah dalam menaikinya karena sepeda motor matic didesain dengan sangat indah yang disukai baik laki-laki maupun perempuan sebagai kenderaan yang sangat disukai masyarakat. untuk mempertahankan posisinya sebagai Market Leaders maka Yamaha selalu menciptakan penemuan-penemuan baru yang mana sesuai dengan perkembangan jaman dan minat konsumen.

Produk dan jasa yang dihasilkan dan ditawarkan suatu perusahaan, hendaknya dapat memenuhi atau dapat memuaskan kebutuhan kebutuhan dan keinginan konsumen, bila tidak akan mengakibatkan produk atau jasa yang dihasilkan perusahaan tersebut tidak dapat diterima oleh pasar atau konsumen, lebih jauh perusahaan akan mengalami kerugian. Dan hal ini berarti aktivitas pemasaran dari perusahaan tersebut akan mengalami hambatan. Kegiatan pemasaran tidak saja dimulai dari usaha menjual sampai berakhir dimana produk atau jasa yang ditawarkan itu terjual habis, melainkan lebih dari pada itu, proses kegiatan pemasaran dimulai dari perencanaan, menentukan harga, memilih saluran distribusi, menetapkan bauran promosi dan seterusnya hingga dapat memuaskan kebutuhan pembeli potensial.

Jadi, pemasaran bukan hanya sekedar aktivitas sederhana untuk menghasilkai penjualan saja, tetapi juga menyangkut aktivitas perusahaan yang berhubungan dengan arus perpindahan barang dan jasa dari tangan produsen hingga ke tangan konsumen akhir, begitu juga yang berhubungan dengan bauran pemasaran tidak terlepas dari bagian dari pemasaran. 


\section{Tinjauan Pustaka}

\section{Bauran Pemasaran (Marketing Mix)}

Bauran pemasaran adalah kumpulan alat pemasaran taktis terkendali yang dipadukan perusahaan untuk mengahasilkan respons yang diinginkannya dipasar sasaran. Kotler dan Amstrong (2008). Dalam bauran pemasaran terdiri dari empat hal yang biasa disebut dengan 4 $P$ : produk, harga, tempat/distribusi dan promosi.

Produk.

Kotler dan Armstrong (2008), menyatakan bahwa produk adalah segala sesuatu yang bisa ditawarkan ke pasar untuk diperhatikan, dimiliki, digunakan, atau dikonsumsi yang bisa memuaskan kebutuhan atau keinginan.

Harga

Menurut Kotler dan Amstrong (2008) harga adalah jumlah dari nilai yang ditukar konsumen atas manfaat-manfaat karena memiliki atau menggunakan produk/jasa. Sementara Lupiyoadi (2012) menyatakan bahwa harga merupakan uang yang dibayarkan oleh konsumen untuk memperoleh jasa yang diinginkan dengan membandingkan antara biaya dan manfaat yang diperoleh (The Consumer's costs and benefits).

Promosi

Promosi adalah proses komunikasi suatu perusahaan dengan pihak-pihak yang berkepentingan sekarang dan yang akan datang serta masyarakat (Kotler, 2005). Definisi lain promosi adalah mengkomunikasikan informasi antara penjual dan pembeli potensial atau orang lain dalam saluran untuk mempengaruhi sikap dan perilaku (McCarthy,dkk, 2011)

\section{Tempat atau Distribusi}

Program distribusi dan penjualan dapat didefinisikan sebagai program yang terdiri atas berbagai kegiatan pemasaran yang berusaha memperlancar dan mempermudah penyampaian barang dan jasa dari produsen kepada konsumen, sehingga penggunaanya sesuai dengan yang diperlukan. (Tjiptono, 2011) Sementara Hurriyati (2009) menyampaikan bahwa Place dapat diartikan sebagai saluran distribusi (zero channel, two level channel, dan multilevel channel).

Dalam pemasaran jasa, ada elemen-elemen lain yang bisa dikontrol dan dikoordinasikan untuk keperluan komunikasi dengan dan memuaskan konsumen jasa. Elemenelemen tersebut adalah, orang (people), lingkungan fisik di mana jasa akan diberikan atau bukti fisik (physical evidence), dan proses jasa itu sendiri (process). Dengan demikian 4P yang pada mulanya menjadi bauran pemasaran barang, perlu diperluas menjadi 7P jika ingin digunakan dalam pemasaran jasa (Yazid, 2013:18).

\section{Orang (People)}

Menurut Lupiyoadi dan Hamdani (2010) dalam hubungannya dengan pemasaran jasa, maka 'orang' yang berfungsi sebagai penyedia jasa sangat memengaruhi kualitas jasa yang diberikan. Keputusan dalam 'orang' ini berarti berhubungan dengan seleksi,pelatihan, motivasi dan manajemen sumber daya manusia.

Proses

Menurut Lupiyodi dan Hamdani (2010) proses merupakan gabungan semua aktifitas, umumnya terdiri atas prosedur, jadwal pekerjaan, mekanisme, aktifitas, dan hal hal rutin, dimana jasa dihasilkan dan disampaikan kepada konsumen.

\section{Lingkungan Fisik}

Menurut Lupiyoadi dan Hamdani (2009) Lingkungan fisik merupakan tempat jasa diciptakan dan langsung berinteraksi dengan konsumen.

\section{Pengertian Keputusan Pembelian}

Keputusan pembelian adalah keputusan konsumen mengenai preferensi atas merekmerek yang ada di dalam kumpulan pilihan (Kotler dan Keler, 2009). Definisi lain keputusan pembelian adalah keputusan pembeli tentang merek mana yang dibeli (Kotler dan Amstrong, 2008). Lebih dalam Kotler (2005) menjelaskan bahwa proses pengambilan keputusan 
merupakan sebuah pendekatan penyelesaian masalah yang terdiri dari lima tahap, yaitu : Menganalisa kebutuhan dan keinginan, menilai sumber-sumber, menetapkan tujuan pembelian, mengidentifikasi alternative pembelian dan keputusan membeli.

\section{Kerangka Konseptual}

Berdasarkan teori pada tinjauan pustaka sebagaimana telah diuraikan pada sebelumnya, dapat disusun suatu kerangka konseptual untuk menganalisis pengaruh bauran pemasaran terhadap keputusan pembelian. Adapun dimensi dari bauran pemasaran yang terdiri dari 7p, yaitu : produk (X1), Harga/price (X2), Promosi (X3), tempat/place (X4), orang/people (X5), Lingkungan Fisik/physical evidence (X6), dan proses (X7) akan diteliti pengaruh terhadap keputusan pembelian motor Yamaha di PD. Panca Motor Prabumulih.

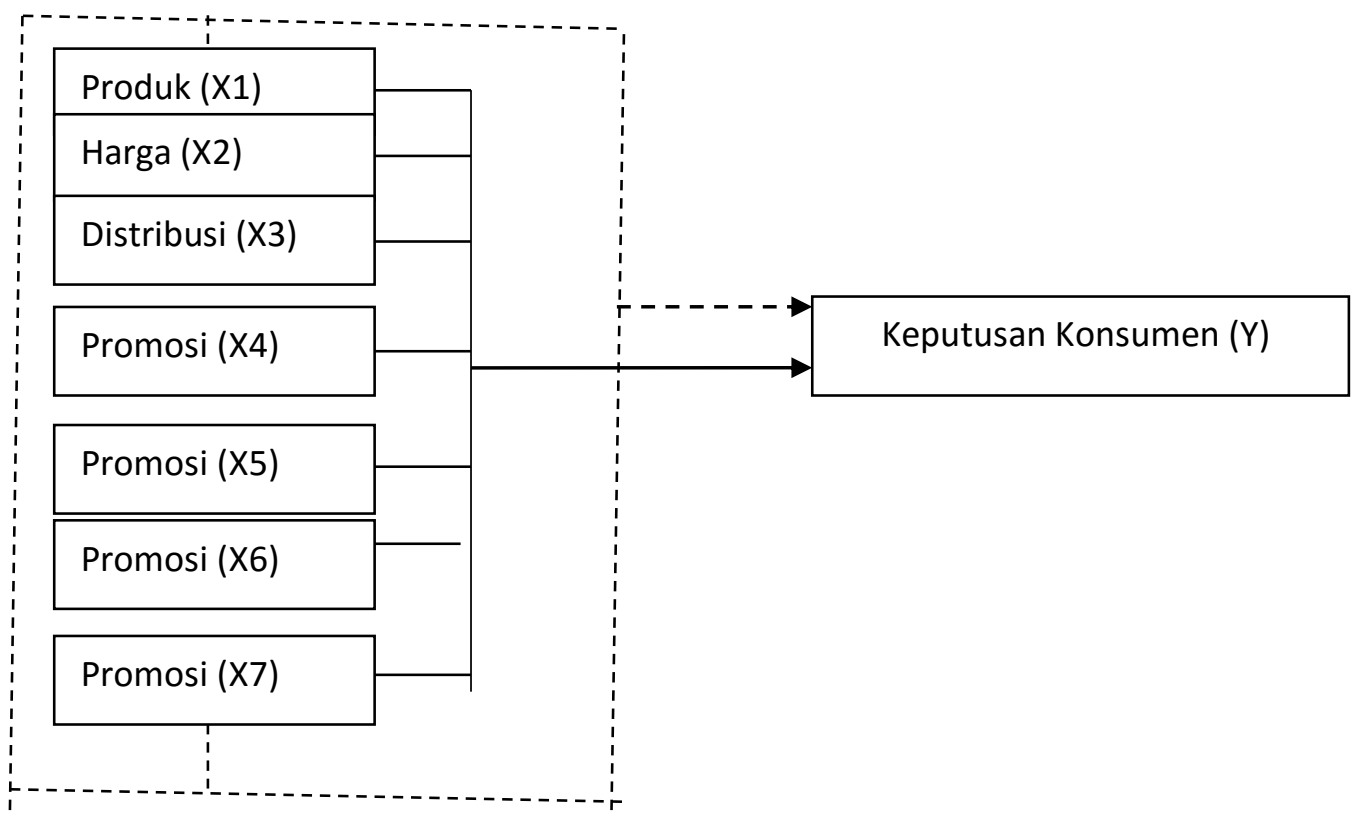

\section{Gambar 1: Kerangka Pemikiran}

\section{Keterangan:}

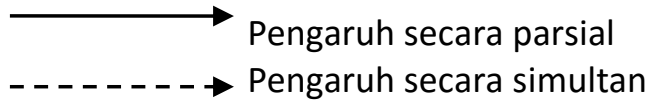

\section{Hipotesis Penelitian}

Berdasarkan kerangka pemikiran yang telah dikemukakan peneliti, menetapkan hipotesis sebagai berikut:

H1 : Diduga ada pengaruh yang positif dan signifikan Produk terhadap keputusan pembelian motor Yamaha di PD. Panca Motor Prabumulih

H2 : Diduga ada pengaruh yang positif dan signifikan Harga/Price terhadap keputusan pembelian motor Yamaha di PD. Panca Motor Prabumulih

H3 : Diduga ada pengaruh yang positif dan signifikan Promosi terhadap keputusan pembelian motor Yamaha di PD. Panca Motor Prabumulih

H4 : Diduga ada pengaruh yang positif dan signifikan Tempat/Place terhadap keputusan pembelian motor Yamaha di PD. Panca Motor Prabumulih

H5 : Diduga ada pengaruh yang positif dan signifikan Orang/People terhadap keputusan pembelian motor Yamaha di PD. Panca Motor Prabumulih

H6: Diduga ada pengaruh yang positif dan signifikan Lingkungan fisik/Physical evidence terhadap keputusan pembelian motor Yamaha di PD. Panca Motor Prabumulih 
H7: Diduga ada pengaruh yang positif dan signifikan Proses terhadap keputusan pembelian motor Yamaha di PD. Panca Motor Prabumulih

H8: Secara simultan diduga ada pengaruh yang positif dan signifikan ketujuh variabel (Produk, Harga/Price, Promosi, Tempat/Place, Orang/People, Lingkungan fisik/Physical evidence, dan Proses ) terhadap keputusan pembelian.

\section{Metode Penelitian \\ Waktu dan Wilayah Penelitian}

Penelitian ini akan dilaksanakan di PD. Panca Motor Prabumulih. Penelitian ini akan dilaksanakan pada bulan Maret sampai dengan bulan Oktober 2018. Penentuan lokasi dilakukan dengan sengaja (purposive) dengan pertimbangan bahwa Pengaruh bauran pemasaran Terhadap keputusan pembelian Pada PD. Panca Motor Prabumulih merupakan salah satu perusahaan dealer resmi produk motor merek Yamaha yang menjual berbagai tipe motor merek Yamaha dengan populasi yang cukup dan berasal dari beberapa konsumen dalam hal ini pelanggan yang membeli motor di PD. Panca Motor Prabumulih

\section{Rancangan Penelitian}

Metode yang digunakan dalam penelitian ini adalah metode survey. Data yang dikumpulkan terdiri dari data primer dan data sekunder. Data primer diperoleh melalui metode wawancara yang dilengkapi dengan kuisioner yang telah disiapkan. Data sekunder diperoleh dari lembaga yang terkait, serta beberapa sumber pustaka baik berupa jurnal maupun buku yang berhubungan dengan penelitian ini. Dan desain penelitian yang digunakan adalah desain asosiatif kausal. Dalam penelitian ini, yang akan dianalisis adalah pengaruh bauran pemasaran yang terdiri dari Produk, Harga/Price, Promosi, Tempat/Place, Orang/People, Lingkungan fisik/Physical evidence, dan Proses,

\section{Prosedur Dan Pengumpulan Data}

Dilihat dari segi cara dan teknik pengumpulan data, maka teknik pengumpulan data dapat dilakukan dengan interview (wawancara) kuesioner (angket) Observasi (pengamatan) dan gabungan ketiganya. Dalam penelitian ini digunakan cara pengumpulan data sebagai berikut :

1. Kuesioner

Metode pengumpulan data yang dilakukan dengan cara memberi seperangkat pertanyaan atau pernyataan tertulis kepada responden untuk dijawabnya. Dan pertanyaan itu telah dipersiapkan sebelumnya secara sistematis.

2. Interview

Metode pengumpulan data dengan mengadakan wawancara secara langsung kepada objek untuk memperoleh data yang diperlukan sesuai dengan kuesioner yang telah disampaikan.

\section{Uji validitas}

Uji Validitas yang diperlukan agar memperoleh instrument yang valid artinya instrument yang tepat untuk mengukur apa yang seharusnya diukur. Uji validitas dapat dilakukan dengan cara mengkorelasikan skor tiap butir dengan skor total yang merupakan jumlah tiap skor pertanyaan yang dijawab oleh responden. Sebelum kuisioner digunakan untuk dua jenis validitas mengumpulkan data, terlebih dahulu diuji validitasnya, dengan menggunakan runus teknik kolerasi item total product moment. Skor setiap pertanyaan yang diuji validitasnya dikolerasikan dengan skor total seluruh item. Nilai skor dari kolerasi antara setiap pertanyaan dengan item nilaai total ini dibandingkan dengan nilai table $r$ product moment. Jika nilai kolerasi lebih besar dari nilai $r$ person product moment maka item yang bersangkutan valid, jika lebih kecil maka item yang bersagkutan tidak valid dan dikeluarkan dari kuisioner. Semakin tinggi nilai koefesien menunjukan semakin tinggi validitas item tersebut (Ariyanto;2014;135).

Uji Reliabilitas 
Reliabilitas adalah indeks yang menunjukkan sejauh mana suatu alat pengukuran dapat dipercaya atau dapat diandalkan dan sejauh mana hasil pengukuran tetap konsisten bila dilakukan pengukuran dua kali atau lebih terhadap gejala yang sama, dengan alat ukur yang sama (Singarimbun, 2011:140). Hasilnya ditunjukkan oleh sebuah indeks yang menunjukkan seberapa jauh sebuah alat ukur dapat diandalkan. Pengujian reliabilitaas instrument ini dilakukan dengan SPSS dengan melihat nilai Cronbach alpha. Jika nilai Cronbach alpha diatas 0,6 maka variabel tersebut adalah Reliabel.

\section{Analisis Regresi Berganda}

Metode yang digunakan dalam penelitian ini adalah metode analisi kuantitatif, metode ini merupakan suatu metode analisa data yang menggunakan angka-angka agar pemecahan masalah dapat dihitung secara pasti dengan perhitungan matematik (Abdurahman; 2011:223) Adapun tahapan analisi kuantitatif yang digunakan untuk menganalisis data dalam penelitian ini adalah:

a. Analisis Regresi

Berdasarkan permasalahaan hipotesis yang diajukan, alat teknis analisis statika yang digunakan adalah analisi regresi linier sederhana dan berganda sehingga metode analisis yang digunakan dalam penelitian ini adalah sebagai berikut:

$$
\begin{array}{ll}
Y=a+b_{1} x_{1}+b_{2} x_{2}+b_{3} x_{3}+b_{4} x_{4}+b_{5} x_{5}+b_{6} x_{6}+b_{7} x_{7}+e \\
\text { Dimana : } \\
Y \quad=\text { Keputusan Pembelian } \\
a & =\text { Konstanta } \\
b_{1} b_{2} & =\text { Koefesien Regresi } \\
x_{1} & =\text { Produk } \\
x_{2} & =\text { Harga } \\
x_{3} & =\text { Tempat } \\
x_{4} & =\text { Promosi } \\
x_{5} & =\text { Orang } \\
x 6 & =\text { Lingkungan fisik } \\
x 7 & =\text { Proses } \\
\text { e } & =\text { Error term (Kesadaran pengganggu yang dalam perhitungan nilainya }
\end{array}
$$

\section{Uji Hipotesis}

\section{Uji Signifikansi Pengaruh Parsial (Uji t)}

Pengujian ini dilakukan untuk mengetahui apakah secara individu variabel independen mempunyai pengaruh secara signifikan terhadap variabel dependen dengan asumsi variabel independen lainnya konstan.

Dasar pengambilan keputusan adalah dengan menggunakan angka probabilitas signifikansi, yaitu :
a. Apabila angka probabilitas signifikansi $>0,05$, maka Ho diterima dan Ha ditolak
b. Apabila angka probabilitas signifikansi <0,05, maka Ho ditolak dan Ha dietrima.

\section{Uji Signifikansi Simultan (Uji f)}

Dalam penelitian ini, uji f digunakan untuk mengetahui tingkat signifikansi pengaruh variable-variabel independen secara bersama-sama (simultan) terhadap variable dependen (Ghozali, 2007:84).

Dasar pengambilan keputusan adalah dengan menggunakan angka probabilitas signifikansi, yaitu :

a. Apabila angka probabilitas signifikansi $>0,05$, maka Ho diterima dan Ha ditolak

b. Apabila angka probabilitas signifikansi $<0,05$, maka Ho ditolak dan Ha dietrima.

\section{Koefisien Determinasi (Uji R2)}

Uji koefisien determinasi (Uji R2) dimaksudkan untuk mengetahui tingkat ketepatan baik dalam analisa regresi dimana hal yang ditunjukkan oleh besarnya koefisien determinasi 
(Uji R2) antara 0 (nol) dan 1 (satu). Koefisien determinasi (Uji R2) nol variable independen sama sekali tidak berpengaruh terhadap variable dependen. Selain itu koefisien determinasi (Uji R2) dipergunakan untuk mengetahui prosentase perubahan variabel tidak bebas ( $\mathrm{Y}$ ) yang disebabkan oleh variabel bebas. Dan uji ini digunakan untuk mengetahui seberapa jauh proporsi variasi dependen (Setiaji, 2012: 29).

\section{Hasil dan Pemabahasan \\ Uji Validitas}

Pengujian validitas selengkapnya dapat dilihat pada Tabel 1 Dibawah ini :

Tabel 1 Hasil Uji Validitas Variabel Produk $\left(\mathrm{X}_{1}\right)$

\begin{tabular}{ccccc}
\hline No & Pertanyaan variable Produk $\left(\mathrm{X}_{1}\right)$ & $\mathrm{r}_{\text {hitung }}$ & $\mathrm{r}_{\text {tabel }}$ & Keterangan \\
\hline 1 & $\begin{array}{c}\text { Barang-barang yang dijual di PD. Panca Motor } \\
\text { merupakan produk yang berkualitas }\end{array}$ & 0,627 & 0,317 & Valid \\
\hline 2 & $\begin{array}{c}\text { Produk-produk yang ditawarkan selalu } \\
\text { mengikuti trend }\end{array}$ & 0,649 & 0,317 & Valid \\
\hline 3 & $\begin{array}{c}\text { Inovasi dari produk yang dijual selalu } \\
\text { mengalami perubahan }\end{array}$ & 0,684 & 0,317 & Valid \\
\hline 4 & $\begin{array}{c}\text { Jika membeli produk yang ada di PD. Panca } \\
\text { Motor merupakan kepuasan tersendiri }\end{array}$ & 0,767 & 0,317 & Valid \\
\hline 5 & $\begin{array}{c}\text { Produk barang jadi yang dijual merupakan } \\
\text { untuk kebutuhan fisik yang sesuai dengan } \\
\text { kebutuhan }\end{array}$ & 0,665 & 0,317 & Valid \\
\hline
\end{tabular}

Tabel 2 Hasil Uji Validitas Variabel Harga $\left(\mathbf{X}_{\mathbf{2}}\right)$

\begin{tabular}{ccccc}
\hline No & Pertanyaan variable Harga (X2) & rhitung & rtabel & Keterangan \\
\hline 1 & $\begin{array}{c}\text { Produk-produk yang dijual di PD. Panca } \\
\text { Motor dengan harga yang sesuai dengan } \\
\text { kualitas barangnya }\end{array}$ & 0,450 & 0,317 & Valid \\
\hline 2 & $\begin{array}{c}\text { Persaingan harga barang yang ada di PD. } \\
\text { Panca Motor sangat kompotitif }\end{array}$ & 0,626 & 0,317 & Valid \\
\hline 3 & $\begin{array}{c}\text { Barang-barang yang dijual di PD. Panca } \\
\text { Motor sangat Murah dengan kualitas yang } \\
\text { baik }\end{array}$ & 0,520 & 0,317 & Valid \\
\hline 4 & $\begin{array}{c}\text { Barang-barang yang dijual di PD. Panca } \\
\text { Motor merupakan produk yang mahal dan } \\
\text { bermerek }\end{array}$ & 0,747 & 0,317 & Valid \\
\hline 5 & $\begin{array}{c}\text { Penetapan harga untuk setiap produk yang } \\
\text { ada sudah sesuai dengan produk yang ada di } \\
\text { pasaran/harga yang wajar }\end{array}$ & 0,763 & 0,317 & Valid \\
\hline
\end{tabular}

Tabel 3 Hasil Uji Validitas Variabel Distribusi $\left(X_{3}\right)$

\begin{tabular}{ccccc}
\hline No & Pertanyaan variabel Distribusi (X3) & rhitung & rtabel & Keterangan \\
\hline 1 & $\begin{array}{c}\text { Kedatangan pendistribusian produk sering } \\
\text { terlambat }\end{array}$ & 0,707 & 0,317 & Valid \\
\hline 2 & $\begin{array}{c}\text { Apabila butuh suatu produk yang diinginkan } \\
\text { selalu ada di PD. Panca Motor }\end{array}$ & 0,616 & 0,317 & Valid \\
\hline 3 & $\begin{array}{c}\text { Untuk mendapatkan produk sangat mudah } \\
\text { didapat apabila diperlukan }\end{array}$ & 0,789 & 0,317 & Valid \\
\hline 4 & $\begin{array}{c}\text { Saluran distribusi untuk produk-produk yang } \\
\text { tersedia sangat lancar }\end{array}$ & 0,615 & 0,317 & Valid \\
\hline 5 & Persediaan barang-barang kebutuhan & 0,549 & 0,317 & Valid \\
\hline
\end{tabular}


konsumen cukup memadai

Tabel 4 Hasil Uji Validitas Variabel Promosi $\left(\mathrm{X}_{4}\right)$

\begin{tabular}{ccccc}
\hline No & Pertanyaan variable Promosi (X4) & rhitung & rtabel & Keterangan \\
\hline 1 & $\begin{array}{c}\text { Kualitas periklananan yang dilakukan di PD. } \\
\text { Panca Motor sangat baik }\end{array}$ & 0,403 & 0,317 & Valid \\
\hline 2 & $\begin{array}{c}\text { Kualitas produk yang ada diperkuat dengan } \\
\text { periklanan yang intensif. }\end{array}$ & 0,477 & 0,317 & Valid \\
\hline 3 & $\begin{array}{c}\text { Dengan adanya iklan yang selalu } \\
\text { mempromosikan produknya konsumen } \\
\text { akan mudah mengenal dan memperoleh } \\
\text { barang yang diinginkan }\end{array}$ & 0,620 & 0,317 & Valid \\
\hline 4 & $\begin{array}{c}\text { Produk-produk yang ada di PD. Panca } \\
\text { Motor sering diiklankan di media cetak } \\
\text { maupun elektronik }\end{array}$ & 0,755 & 0,317 & Valid \\
\hline 5 & $\begin{array}{c}\text { Promosi bagian terpenting untuk produk- } \\
\text { produk yang dijual di PD. Panca Motor }\end{array}$ & 0,565 & 0,317 & Valid \\
\hline
\end{tabular}

Tabel 5 Hasil Uji Validitas Variabel Orang $\left(X_{5}\right)$

\begin{tabular}{ccccc}
\hline No & Pertanyaan variabel Orang (X5) & rhitung & rtabel & Keterangan \\
\hline 1 & $\begin{array}{c}\text { Mengetahui produk yang ada di PD Panca } \\
\text { Motor tahu dari konsumen lain }\end{array}$ & 0,803 & 0,317 & Valid \\
\hline 2 & $\begin{array}{c}\text { Persepsi yang diberikan konsumen lain } \\
\text { membuat tertarik untuk membeli kembali }\end{array}$ & 0,718 & 0,317 & Valid \\
\hline 3 & $\begin{array}{c}\text { Penyampain tentang produk dari mulut ke } \\
\text { mulut konsumen merupakan yang efektif }\end{array}$ & 0,642 & 0,317 & Valid \\
\hline 4 & $\begin{array}{c}\text { Bagi Konsumen sudah sangat mengenal PD. } \\
\text { Panca Motor dari persepsi konsumen lain }\end{array}$ & 0,657 & 0,317 & Valid \\
\hline 5 & $\begin{array}{c}\text { Faktor-faktor yang meningkatkan penjualan } \\
\text { di PD. Panca Motor disebabkan persepsi } \\
\text { yang baik dari konsumen }\end{array}$ & 0,828 & 0,317 & Valid \\
\hline & & & & \\
\hline
\end{tabular}

Tabel 6 Hasil Uji Validitas Variabel Proses $\left(X_{6}\right)$

\begin{tabular}{|c|c|c|c|c|}
\hline No & Pertanyaan variabel Proses (X6) & rhitung & rtabel & Keterangan \\
\hline 1 & $\begin{array}{c}\text { Pelayanan yang diberikan oleh PD. Panca Motor } \\
\text { sesuai dengan system yang berlaku }\end{array}$ & 0,750 & 0,317 & Valid \\
\hline 2 & $\begin{array}{l}\text { Pelayanan dari PD. Panca motor memiliki cara } \\
\text { yang menarik dan mudah dipahami }\end{array}$ & 0,826 & 0,317 & Valid \\
\hline 3 & $\begin{array}{l}\text { Dalam melayani konsumen mempunyai cara } \\
\text { yang unik dan khusus }\end{array}$ & 0,620 & 0,317 & Valid \\
\hline 4 & $\begin{array}{l}\text { Pelayanan proses mendapatkan produk tidak } \\
\text { berbelit-belit }\end{array}$ & 0,747 & 0,317 & Valid \\
\hline 5 & $\begin{array}{c}\text { sistem yang berlangsung dalam } \\
\text { penyelenggaraan dan menentukan mutu } \\
\text { kelancaran penyelenggaraan jasa yang dapat } \\
\text { memberikan kepuasan pada pengguna } \\
\text { produknya }\end{array}$ & 0,763 & 0,317 & Valid \\
\hline
\end{tabular}


Tabel 7 Hasil Uji Validitas Variabel Lingkungan Fisik $\left(X_{7}\right)$

\begin{tabular}{ccccc}
\hline No & Pertanyaan variable Promosi (X4) & rhitung & rtabel & Keterangan \\
\hline 1 & $\begin{array}{c}\text { Untuk internet/web pages sudah tersedia } \\
\text { dan mudah di akses oleh konsumen }\end{array}$ & 0,607 & 0,317 & Valid \\
\hline 2 & $\begin{array}{c}\text { Dokumen selalu diutamakan dalam } \\
\text { transaksi seperti invoice, catatan } \\
\text { pengiriman dll }\end{array}$ & 0,816 & 0,317 & Valid \\
& $\begin{array}{c}\text { Sebelum membeli produk yang ditawarkan } \\
\text { selalu disediakan brosus }\end{array}$ & 0,789 & 0,317 & Valid \\
\hline 3 & $\begin{array}{c}\text { Gedung kantor PD. Panca Motor memiliki } \\
\text { lay out gedung yang menarik }\end{array}$ & 0,615 & 0,317 & Valid \\
\hline 5 & $\begin{array}{c}\text { Karyawan PD. Panca Motor sudah memiliki } \\
\text { pakaian seragam yang telah ditetapkan }\end{array}$ & 0,749 & 0,317 & Valid \\
\hline
\end{tabular}

Tabel 8 Hasil Uji Validitas Variabel Keputusan Konsumen (Y)

\begin{tabular}{|c|c|c|c|c|}
\hline No & Pertanyaan variabel Distribusi (X3) & rhitung & rtabel & Keterangan \\
\hline 1 & $\begin{array}{c}\text { Konsumen bisa membeli merek produk } \\
\text { yang diinginkan kualitas produk yang ada di } \\
\text { PD. Panca Motor memuaskan }\end{array}$ & 0,603 & 0,317 & Valid \\
\hline 2 & $\begin{array}{l}\text { Jika menginginkan membeli produk dengan } \\
\text { merek yang disukai selalu tersedia }\end{array}$ & 0,718 & 0,317 & Valid \\
\hline 3 & $\begin{array}{l}\text { Merek produk yang ada di PD. Panca Motor } \\
\text { tidak meragukan lagi }\end{array}$ & 0,842 & 0,317 & Valid \\
\hline 4 & $\begin{array}{l}\text { Konsumen untuk membeli kembali suatu } \\
\text { produk yang ada di PD. Panca Motor tanpa } \\
\text { ada lagi pertimbangan untuk membeli } \\
\text { produk di tempat lain. }\end{array}$ & 0,657 & 0,317 & Valid \\
\hline 5 & $\begin{array}{c}\text { Produk dengan harga yang murah } \\
\text { membuat konsumen ingin membeli } \\
\text { kembali }\end{array}$ & 0,728 & 0,317 & Valid \\
\hline 6 & $\begin{array}{c}\text { Dengan sering adanya subsidi konsumen } \\
\text { akan mengulang pembelian }\end{array}$ & 0,798 & 0,317 & Valid \\
\hline 7 & $\begin{array}{c}\text { PD. Panca Motor memilih tempat } \\
\text { penjualan yang strategis sehingga } \\
\text { konsumen sangat mudah menjangkaunya }\end{array}$ & 0,675 & 0,317 & Valid \\
\hline 8 & $\begin{array}{l}\text { Produk yang ditawarkan dengan harga } \\
\text { yang sesuai dengan produk yang dijual }\end{array}$ & 0,798 & 0,317 & Valid \\
\hline 9 & $\begin{array}{l}\text { Produk-produk yang tersedia di PD. Panca } \\
\text { Motor dengan merek yang telah melekat } \\
\text { dihati konsumen }\end{array}$ & 0,837 & 0,317 & Valid \\
\hline 10 & $\begin{array}{l}\text { Pelayanan yang diberikan ramah, sopan } \\
\text { dan aktif dalam melayani konsumen }\end{array}$ & 0,757 & 0,317 & Valid \\
\hline
\end{tabular}

Tabel di atas menunjukan bahwa semua indikator yang digunakan untuk mengukur variabel-variabel produk $\left(X_{1}\right)$, harga $\left(X_{2}\right)$, distribusi $\left(X_{3}\right)$ Dan promosi $\left(X_{4}\right)$, Orang $(X 5)$, Proses $\left(X_{6}\right)$, Lingkungan Fisik $\left(X_{7}\right)$ dan variabel Keputusan konsumen $(Y)$ yang digunakan dalam penelitian ini mempunyai nilai korelasi yang lebih besar dari 0,317. Dari hasil tersebut menunjukan bahwa indikator tersebut adalah valid. 


\section{Uji Reliabilitas}

Pengujian reliabilitas dalam penelitian ini adalah dengan menggunakan rumus cronbach Alpha. Menurut Uma Sekaran (2012), pengambilan keputusan untuk uji

reliabilitas sebagai berikut :

- Cronbach Alpha $<0,6=$ reliabilitas buruk

- Cronbach Alpha 0,6-0,79 = reliabilitas diterima

- Cronbach Alpha 0,8 = reliabilitas baik

Hasil pengujian reliabilitas untuk masing-masing variabel yang diringkas pada Tabel Berikut ini :

Tabel 9 Hasil Pengujian Reliabilitas

\begin{tabular}{lll}
\hline \multicolumn{1}{c}{ Variabel } & Alpha & ketererangan \\
\hline Produk (X1) & 0,756 & Reliabel \\
\hline Harga (X2) & 0,768 & Reliabel \\
\hline Distribusi (X3) & 0,657 & Reliabel \\
\hline Promosi (X4) & 0,766 & Reliabel \\
\hline Orang (X5) & 0,802 & Reliabel \\
\hline Proses (X6) & 0,784 & Reliabel \\
\hline Lingkungan (X7) & 0,816 & Reliabel \\
\hline Keputusan Konsumen (Y) & 0,852 & Reliabel \\
\hline
\end{tabular}

Sumber : Data primer yang diolah, 2019

Hasil uji reliabilitas seperti output SPSS tersebut pada Tabel diatas, menunjukan bahwa semua variabel mempunyaii koefisien Alpha yang lebih besar dari 0,6 sehingga dapat dikatakan semua konsep pengukur masing-masing variabel dari kuesioner adalah reliabel.

\section{Analisis Regresi Linear Berganda}

Perhitungan statistik dalam analisis regresi linear berganda yang digunakan dalam penelitian ini adalah dengan menggunakan bantuan program komputer SPSS. Hasil pengolahan data selengkapnya ada pada lampiran dan selanjutnya akan dijelaskan pada tabel 4.16 berikut :

Tabel 10 Hasil Uji Regresi Linier Berganda

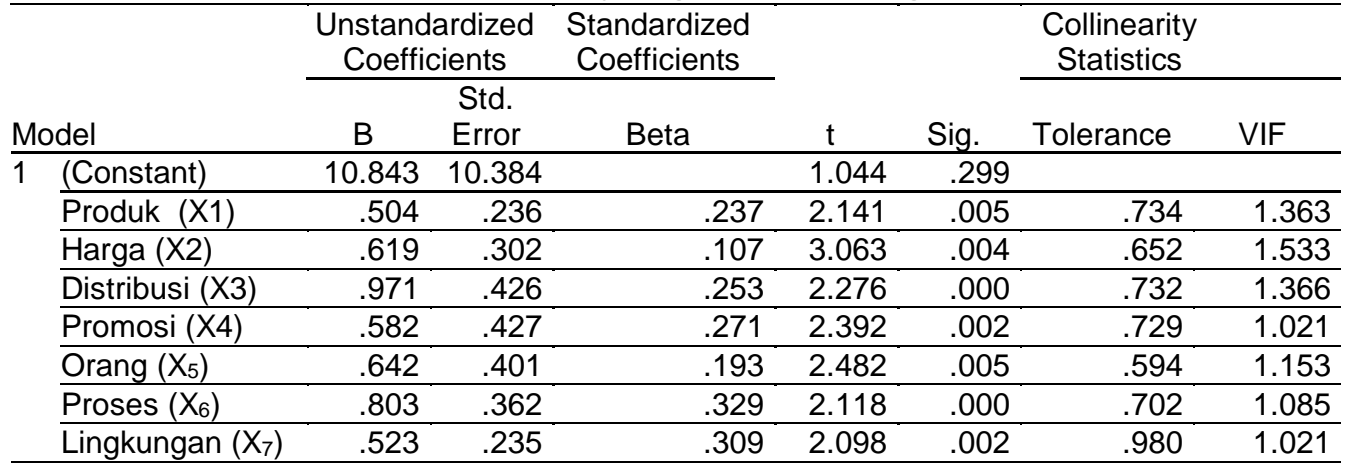

Model persamaan regresi yang dapat dituliskan dari hasil tersebut dalam bentuk persamaan regresi sebagai berikut :

$Y=10,843+0,504 X_{1}+0,619 X_{2}+0,971 X_{3}+0,582 X_{4}+0,642 X_{5}+0,803 X_{6}+0,523 X_{7}$

Berdasarkan hasil regresi pada Tabel tersebut diatas, maka dapat dijelaskan sebagai berikut :

Analisis regresi berganda digunakan untuk mengetahui besarnya pengaruh variabel produk $\left(X_{1}\right)$, kelengkapan harga $\left(X_{2}\right)$, distribusi $\left(X_{3}\right)$, promosi $\left(X_{4}\right)$, Orang $\left(X_{5}\right)$, Proses $\left(X_{6}\right)$ dan Lingkungan $\left(X_{7}\right)$ terhadap keputusan pembelian. Dari Tabel 4.18 hasil regresi linear berganda, diperoleh hasil bahwa produk, harga, distribusi, promosi, secara parsial berpengaruh secara signifikan terhadap keputusan konsumen, hal ini dapat dilihat pada hasil signifikannya yang lebih kecil dari 0,05. 


\section{Uji Hipotesis}

Pengujian hipotesis dalam penelitian bertujuan untuk membuktikan pengaruh produk, harga, distribusi, promosi, orang, proses dan lingkungan fisik terhadap keputusan konsumen PD. Panca Motor Prabumulih. Adapun tabel hasil keputusan konsumen PD. Panca Motor Prabumulih. Adapun tabel hasil uji t dan pengujian hipotesis disajikan sebagai berikut:

Tabel 11 Hasil Uji t

\begin{tabular}{|c|c|c|c|c|c|c|c|c|}
\hline \multirow[b]{2}{*}{ Model } & & \multicolumn{2}{|c|}{$\begin{array}{l}\text { Unstandardized } \\
\text { Coefficients }\end{array}$} & \multirow{2}{*}{$\begin{array}{c}\text { Standardized } \\
\text { Coefficients } \\
\text { Beta } \\
\end{array}$} & \multirow[b]{2}{*}{$\mathrm{t}$} & \multirow[b]{2}{*}{ Sig. } & \multicolumn{2}{|c|}{ Collinearity Statistics } \\
\hline & & B S & Std. Error & & & & Tolerance & VIF \\
\hline \multirow[t]{8}{*}{1} & (Constant) & 10.843 & 10.384 & & 1.044 & .299 & & \\
\hline & Produk (X1) & .504 & .236 & .237 & 2.141 & .005 & .734 & 1.363 \\
\hline & Harga (X2) & .619 & .302 & .107 & 3.063 & .004 & .652 & 1.533 \\
\hline & Distribusi (X3) & 971 & .426 & .253 & 2.276 & .000 & .732 & 1.366 \\
\hline & Promosi (X4) & .582 & .427 & .271 & 2.392 & .002 & .729 & 1.021 \\
\hline & Orang $\left(X_{5}\right)$ & .642 & .401 & 193 & 2.482 & .005 & .594 & 1.153 \\
\hline & Proses $\left(X_{6}\right)$ & .803 & 362 & .329 & 2.118 & .000 & .702 & 1.085 \\
\hline & $\begin{array}{l}\text { Lingkungan } \\
\left(X_{7}\right)\end{array}$ & .523 & .235 & .309 & 2.098 & .002 & 980 & 1.021 \\
\hline
\end{tabular}

\section{Uji t (secara parsial)}

Penjelasan hasil uji t untuk masing-masing variabel bebas adalah sebagai berikut:

1) Hipotesis Pertama

Hasil statistik uji t untuk variabel produk diperoleh nilai t hitung sebesar 2.141 dengan tingkat signifikansi 0,000, karena signifikansi lebih kecil dari $0,05(0,000<0,05)$, dan koefisien regresi mempunyai nilai positif sebesar 0,504 ; maka hipotesis yang menyatakan bahwa "Terdapat pengaruh positif variabel produk terhadap keputusan konsumen PD. Panca Motor Prabumulih" terbukti.

2) Hipotesis Kedua

Hasil statistik uji t untuk variabel harga diperoleh nilai t hitung sebesar 3.063 dengan tingkat signifikansi 0,000, karena signifikansi lebih kecil dari $0,05(0,000<0,05)$, dan koefisien regresi mempunyai nilai positif sebesar 0,619 ; maka hipotesis yang menyatakan bahwa "Terdapat pengaruh positif variabel harga terhadap keputusan konsumen PD. Panca Motor Prabumulih" terbukti.

3) Hipotesis Ketiga

Hasil statistik uji $t$ untuk variabel harga diperoleh nilai t hitung sebesar 2.276 dengan tingkat signifikansi 0,000 , karena signifikansi lebih kecil dari $0,05 \quad(0,000<0,05)$, dan koefisien regresi mempunyai nilai positif sebesar 0,971 ; maka hipotesis yang menyatakan bahwa "Terdapat pengaruh positif variabel distribusi terhadap keputusan konsumen PD. Panca Motor Prabumulih" terbukti.

4) Hipotesis Keempat

Hasil statistik uji t untuk variabel harga diperoleh nilai t hitung sebesar 2.392 dengan tingkat signifikansi 0,000, karena signifikansi lebih kecil dari $0,05(0,000<0,05)$, dan koefisien regresi mempunyai nilai positif sebesar 0,582 ; maka hipotesis yang menyatakan bahwa "Terdapat pengaruh positif variabel promosi terhadap keputusan konsumen PD. Panca Motor Prabumulih" terbukti.

5) Hipotesis Kelima

Hasil statistik uji t untuk variabel orang diperoleh nilai t hitung sebesar 2.482 dengan tingkat signifikansi 0,000 , karena signifikansi lebih kecil dari $0,05(0,000<0,05)$, dan koefisien regresi mempunyai nilai positif sebesar 0,642 ; maka hipotesis yang menyatakan bahwa "Terdapat pengaruh positif variabel orang terhadap keputusan konsumen PD. Panca Motor Prabumulih" terbukti.

6) Hipotesis Keenam 
Hasil statistik uji t untuk variabel harga diperoleh nilai t hitung sebesar 2.118

dengan tingkat signifikansi 0,000, karena signifikansi lebih kecil dari 0,05 $(0,000<0,05)$, dan koefisien regresi mempunyai nilai positif sebesar 0,803; maka hipotesis yang menyatakan bahwa "Terdapat pengaruh positif variabel proses terhadap keputusan konsumen PD. Panca Motor Prabumulih" terbukti.

7) Hipotesis Ketujuh

Hasil statistik uji t untuk variabel harga diperoleh nilai t hitung sebesar 2.098 dengan tingkat signifikansi 0,000, karena signifikansi lebih kecil dari 0,05 $(0,000<0,05)$, dan koefisien regresi mempunyai nilai positif sebesar 0,523; maka hipotesis yang menyatakan bahwa "Terdapat pengaruh positif variabel lingkungan fisik terhadap keputusan konsumen PD. Panca Motor Prabumulih" terbukti.

\section{Uji F (Simultan)}

Uji $\mathrm{F}$ digunakan untuk melihat signifikan tidaknya hubungan variabel independen dengan variabel mediasi secara bersama-sama dan untuk melihat signifikan tidaknya hubungan variabel independen dengan variabel dependen secara bersama-sama, sedangkan koefisien beta digunakan untuk melihat arah hubungan pengaruh variabel independen terhadap variabel dependen. Dasar penelitian ini adalah menurut Ghozali (2011:56).

Adapun hasil pengujian signifikansi dari uji $\mathrm{F}$ disajikan sebagai berikut:

1) Pengaruh variabel produk, Harga, distribusi, promosi, orang, proses dan lingkungan fisik terhadap keputusan konsumen PD. Panca Motor Kota Prabumulih. Hasil perhitungan regresi secara bersama-sama diperoleh pada Tabel 4.18 berikut :

Tabel 12 Hasil Analisis Regresi Secara Bersama-sama

\begin{tabular}{|c|c|c|c|c|c|c|}
\hline Model & & $\begin{array}{l}\text { Sum of } \\
\text { Squares }\end{array}$ & df & $\begin{array}{l}\text { Mean } \\
\text { Square } \\
\end{array}$ & $\mathrm{F}$ & Sig. \\
\hline \multirow[t]{3}{*}{1} & Regression & 346.917 & 4 & 86.729 & 3.998 & $.005^{\mathrm{b}}$ \\
\hline & Residual & 2061.083 & 95 & 21.696 & & \\
\hline & $\overline{\text { Total }}$ & 2408.000 & 99 & & & \\
\hline
\end{tabular}

Pengujian pengaruh variabel bebas secara bersama-sama terhadap variabel terikat dilakukan dengan menggunakan uji $\mathrm{F}$. Hasil perhitungan statistik menunjukan nilai Fhitung = 3,998 dengan signifikansi sebesar 0,005 $<0,05$ Dengan nilai signifikansi dibawah 0,05 menunjukan bahwa secara bersama-sama produk, harga, distribusi, promosi, orang, proses dan lingkungan fisik mempunyai pengaruh yang positif dan signifikan terhadap Keputusan konsumen, hal ini berarti hipotesis ketujuh diterima.

\section{Koefisien Determinasi}

Hasil dari pengolahan data yang menggunakan bantuan program SPSS, juga menghasilkan output berupa tabel koefisien model summary. Analisis koefisien determinasi ini menghasilkan gambaran seberapa signifikan pengaruh secara simultan variabel indevenden yakini marketing mix terhadap keputusan konsumen PD. Panca Motor Kota Prabumulih seperti terlihat pada Tabel 4.19 berikut:

Tabel 13 Koefisien Determinasi

\begin{tabular}{lrrrr}
\hline Model & R & R Square & $\begin{array}{c}\text { Adjusted R } \\
\text { Square }\end{array}$ & $\begin{array}{r}\text { Std. Error of } \\
\text { the Estimate }\end{array}$ \\
\hline 1 & .880 & .744 & .708 & 4.658
\end{tabular}

Dari output model summary didapatkan tabel determinasi di atas yang memberikan $R$ Square sebesar 0,744 . Hal ini menunjukan bahwa variabel marketing mix (produk, harga, distribusi, promosi, orang, proses dan lingkungan fisik) secara simultan persentase sumbangan pengaruh variabel independent mempunyai pengaruh terhadap variabel dependent (Keputusan konsumen untuk berbelanja), sebesar $74,4 \%$. Atau variabel independent (produk, harga, distribusi, promosi orang, proses dan lingkungan fisik) mampu 
menjelaskan sebesar $74,4 \%$ variabel dependent (Keputusan konsumen untuk berbelanja), sedangkan sisanya $25,6 \%$ dipengaruhi atau dijelaskan oleh variabel lain yang tidak diteliti dalam penelitian ini.

\section{Penutup \\ Kesimpulan}

Berdasarkan hasil analisis yang telah dilakukan pada penelitian ini diperoleh hasil uji, maka dapat diambil beberapa kesimpulan sebagai berikut :

1. Dari hasil Uji $t$ variabel produk mempunyai pengaruh signifikan terhadap Keputusan konsumen PD. Panca Motor Kota Prabumulih. Hal ini dapat dibuktikan dengan melihat nilai $\mathrm{t}$ hitung $>\mathrm{t}$ tabel $(2.141>1.98)$. Variabel harga mempunyai pengaruh signifikan terhadap Keputusan konsumen PD. Panca Motor Kota Prabumulih hal ini dibuktikan dengan menilai t hitung $>\mathrm{t}$ tabel $(3.063>1.98)$ Variabel distribusi mempunyai pengaruh signifikan terhadap Keputusan konsumen PD. Panca Motor Kota Prabumulih. Hal ini dapat dibuktikan dengan melihat $t$ hitung $>t$ tabel $(2.276>1.98)$ Variabel promosi mempunyai signifikansi terhadap Keputusan konsumen PD. Panca Motor Kota Prabumulih. Hal ini dapat dibuktikan dengan melihat nilai $\mathrm{t}$ hitung $>\mathrm{t}$ tabel $(2.392>1.98)$. Variabel orang mempunyai pengaruh signifikan terhadap Keputusan konsumen PD. Panca Motor Kota Prabumulih. Hal ini dapat dibuktikan dengan melihat $t$ hitung $>t$ tabel $(2.482>1.98)$. Variabel proses mempunyai pengaruh signifikan terhadap Keputusan konsumen PD. Panca Motor Kota Prabumulih. Hal ini dapat dibuktikan dengan melihat $\mathrm{t}$ hitung $>\mathrm{t}$ tabel $(2.118>1.98)$. dan terakhir Variabel lingkungan fisik mempunyai pengaruh signifikan terhadap Keputusan konsumen PD. Panca Motor Kota Prabumulih. Hal ini dapat dibuktikan dengan melihat $\mathrm{t}$ hitung $>\mathrm{t}$ tabel $(2.098>$ 1.98).

2. Pengujian pengaruh variabel bebas secara bersama-sama terhadap variabel terikat dilakukan dengan menggunakan uji $\mathrm{F}$. Hasil perhitungan statistik menunjukan nilai Fhitung = 3,998 dengan signifikansi sebesar 0,005 0,05 Dengan nilai signifikansi dibawah 0,05 menunjukan bahwa secara bersama-sama produk, harga, distribusi dan promosi mempunyai pengaruh yang positif dan signifikan terhadap Keputusan konsumen PD. Panca Motor Kota Prabumulih.

3. Perhitungan koefisien determinasi $\left(R^{2}\right)$ digunakan untuk mengetahui berapa persen variasi variabel dependen dapat dijelaskan oleh variasi variabel independen. Dalam penelitian ini diperoleh angka $\mathrm{R}^{2}$ sebesar 0.744 atau $74.4 \%$ variasi variabel Keputusan konsumen dapat dijelaskan oleh variasi variabel produk (product), harga (price), distribusi (place), promosi (promotion), orang, proses dan lingkungan fisik sedangkan sisanya $25,6 \%$ dijelaskan oleh variasi variabel lain yang tidak diteliti dalam penelitian ini.

4. Dari hasil uji regresi linier berganda. Diperoleh bahwa variabel marketing mix yang paling dominan adalah variabel harga sebesar 3.063 disusul variabel-variabel distribusi sebesar 2.276, variabel produk sebesar 2.141 dan yang terakhir variabel promosi sebesar 2.098, variabel orang 2.482 , variabel proses 2.118 dan yang terakhir variabel lingkungan fisik sebesar 2.098

Saran

Berdasarkan hasil dan simpulan penelitian ini, penulis memberikan saran untuk PD. Panca Motor Kota Prabumulih untuk dapat meningkatkan dalam hal peningkatan marketing mix (produk, harga, distribusi, promosi, orang, proses dan lingkungan fisik) karena dengan adanya marketing mix yang lebih baik, hal ini dapat meningkatkan Keputusan konsumen terhadap PD. Panca Motor Kota Prabumulih

Untuk penelitian selanjutnya atau yang akan datang disarankan untuk melakukan peneltian terhadap faktor lain yang tentunya dapat mempengaruhi variabel dependen terhadap Keputusan konsumen, agar lebih melengkapi penelitian ini yang mungkin bisa mempengaruhi Keputusan konsumen, seperti faktor kualitas pelayanan, lokasi. Maka bagi 
peneliti berikut hendaknya meneliti masalah kualitas pelayanan, lokasi terhadap Keputusan konsumen yang belum diteliti dalam penelitian ini.

\section{Daftar Pustaka}

Abdurrahman, Fathoni. (2011). Manajemen Sumber Daya Manusia. Jakarta: PT Rineka Cipta.

Cannon, Perreault \& McCarthy. (2010). Pemasaran Dasar Pendekatan Manajerial Global Buku 2 Edisi 16. Jakarta: Salemba Empat

Ghazali, Imam. (2007). Aplikasi Analisi Multivariate dengan Program SPSS. Cetakan ke-IV, Badan Penerbit Universitas Dipenogoro.

Kotler, Philip , \& Amstrong. (2008). Principles of Marketing, Global Edition, 14 Edition, Pearson Education

Kotler, Philip \& Keller. (2009). Manajemen Pemasaran (Edisi Ketiga Belas). Jakarta: Erlangga.

Lupiyoadi, Rambat. (2011) Manajemen Pemasaran Jasa (Teori dan Praktik), Edisi Pertama, Salemba Empat, Jakarta.

Singarimbun, Masri. (2011). Metode Penelitian Survei. Edisi Revisi. Jakarta: LP3ES.

Setiaji Bambang. (2010). Panduan Riset Dengan Pendekatan Kuantitatif. Program Paska Sarjana Universitas Muhammadiyah Surakarta Press. Surakarta.

Sugiyono. (2010). Metode Penelitian Pendidikan Pendekatan Kuantitatif, Kualitatif, dan R\&D. Bandung: ALFABETA.

Singarimbun, Masri \& Sofian Efendi. (2011). Metode Penelitian Survai. LP3ES, Jakarta.

Tjiptono, Fandy. (2011). Manajemen Jasa. Yogyakarta: Andi Offset.

W. Lamb, Charles. (2011). Pemasaran. Jakarta : Salemba Empat. 